\title{
In-Vessel Co-Composting of Food Waste Employing Enriched Bacterial Consortium
}

\author{
Mukesh Kumar Awasthi',2, \\ Quan Wang', Meijing \\ Wang', Hongyu Chen', \\ Xiuna Ren', Junchao Zhao' \\ and Zengqiang Zhang ${ }^{1 *}$ \\ ${ }^{1}$ College of Natural Resources and \\ Environment, Northwest Agricultural \\ and Forestry University, 712100 \\ Yangling, Shaanxi Province, PR China \\ 2Department of Biotechnology, \\ Amicable Knowledge Solution \\ University, 485001 Satna, India
}

Received: July 26, 2017 Accepted: September 8, 2017
*Corresponding author:

Phone: +8613609254113;

Fax: +8602987080055 ;

E-mail:zhangzq58@126.com

ORCID IDs: 0000-0003-0879-184X (Awasthi), 0000-0003-1314-0902 (Wang, Q), 0000-0002-0766-3056 (Wang, M), 0000-0002-5325-9249 (Chen), 0000-0002-0985-2918 (Ren), 0000-0003-0787-4424 (Zhao), 0000-0002-6860-9328 (Zhang)

Paper was presented at the 7th International Forum on Industrial Bioprocessing - IFIBiop 2017, May 21-24, 2017, Wuxi, PR China

\section{SUMMARY}

The aim of the present study is to develop a good initial composting mix using a bacterial consortium and $2 \%$ lime for effective co-composting of food waste in a 60 -litre in-vessel composter. In the experiment that lasted for 42 days, the food waste was first mixed with sawdust and $2 \%$ lime (by dry mass), then one of the reactors was inoculated with an enriched bacterial consortium, while the other served as control. The results show that inoculation of the enriched natural bacterial consortium effectively overcame the oil-laden co-composting mass in the composter and increased the rate of mineralization. In addition, $\mathrm{CO}_{2}$ evolution rate of $(0.81 \pm 0.2) \mathrm{g} /(\mathrm{kg} \cdot$ day $)$, seed germination index of $(105 \pm 3)$ $\%$, extractable ammonium mass fraction of $305.78 \mathrm{mg} / \mathrm{kg}, \mathrm{C} / \mathrm{N}$ ratio of $16.18, \mathrm{pH}=7.6$ and electrical conductivity of $3.12 \mathrm{mS} / \mathrm{cm}$ clearly indicate that the compost was well matured and met the composting standard requirements. In contrast, control treatment exhibited a delayed thermophilic phase and did not mature after 42 days, as evidenced by the maturity parameters. Therefore, a good composting mix and potential bacterial inoculum to degrade the oil are essential for food waste co-composting systems.

Key words: oily food waste, composting mix formulation, bacterial consortium, lime

\section{INTRODUCTION}

Food waste management and its impact on the environment is one of the biggest concerns all over the world. The amount of municipal solid waste is gradually increasing in China and it reached 191 million tonnes in 2015, which was a drastic increase by $22 \%$ from $2005(1,2)$. Around $56 \%$ of the municipal solid waste in China is food waste, which is directly disposed in landfill. Thus, it is necessary to reduce the significant quantity of food waste disposal at landfill because the settlement of landfill is increasing in many metropolises. Moreover, the food waste emits greenhouse gases and highly saline leachate. For these reasons, the direct food waste disposal should be diverted from the landfill. However, most of the countries have implemented policies and regulation to limit the landfill disposal of food waste with municipal solid waste and promote biological treatment $(3,4)$. Aerobic composting of food waste is a highly recommended technology to recycle the organic wastes as composting facilitates the reduction of waste to landfill. Thus, the pollution problem associated with landfilling such as emission of greenhouse gases and generation of toxic leachates could be reduced. The easily degradable organic matter in the food waste intensively acidifies the composting mass during the early phase due to initial rapid fermentation, while the high oil contents negatively affect the physical structure of the composting mass that collectively retards decomposition efficiency (3-6).

Food waste composting in a range of reactors has been extensively considered in recent years, but most of the investigations use either a synthetic food waste with uniform composition or segregated food waste obtained from cafeterias with a limited composition $(2,5,6)$. Microbes can thoroughly mineralize organic matter into carbon dioxide and water by secreting enzymes. Several microbes are involved in various biochemical processes in different phases of composting. Hence, the strategy to inoculate potential microbial 
agents or consortium of microbes is a promising approach for enhancing the properties of the final product $(7,8)$. However, the inoculated microorganisms often suffer from some inherent difficulties such as longer cultivation time and worse competitiveness than indigenous microorganisms in a complex composting system $(9,10)$.

The potential of microbial enzymes to enhance the organic matter transformation has also increasingly become the focus of contemporary research. Despite this, limited research has been focused on the effect of oil content on the composting process. There are not many studies of the effect of the enriched bacterial consortium on the composting of real food waste $(11,12)$, because the properties of food waste differ from place to place, which mostly depends on eating habits. Recently, the use of bacterial consortium in a small-scale composter for the composting of food waste and its ecofriendly disposal has been investigated by many researchers (1115), but some characteristics of food waste, especially low $\mathrm{pH}$ and high oil content, pose serious restrictions to successful application of this method (2). To eliminate the challenges, several studies have examined the use of alkaline materials (e.g. $\mathrm{NaOH}$, fly ash and lime) as $\mathrm{pH}$ alleviating agents in the bio-oxidative phase of composting $(2,6)$. However, high concentrations of alkaline substances tend to affect the microorganisms because of the potential inhibitory effects caused by their high $\mathrm{pH}$. Besides, their addition has some drawbacks as well, such as the loss of nitrogen through $\mathrm{NH}_{3}$ emission $(2,16)$.

Although there are numerous small-scale composters available on the market for food waste composting, handling of real food waste and the problems caused by acidic $\mathrm{pH}$ and oil content have scarcely been reported. Therefore, the present study was designed to evaluate the effect of an enriched bacterial consortium specific to the oily food waste together with the addition of lime on the efficiency of food waste composting using a small-scale in-vessel composter.

\section{MATERIALS AND METHODS}

\section{Composting materials}

For the experiment, the food waste was collected from the Northwest Agricultural and Forestry University (Yangling, PR China) canteen, consisting of steamed rice, wheat meal, soy, fish, meat and lard. The food waste was mixed with sawdust at the ratio of $4: 1$ (by wet mass) to obtain the initial $\mathrm{C} / \mathrm{N}$ ratio between 25 and 30 and bulk density of $\rho=0.5 \mathrm{~kg} / \mathrm{L}$, and $2 \%$ lime (by dry mass) was added to buffer the food waste during composting (3). The sawdust and lime were purchased from a local market (Taobao Pvt, PR China). Selected properties of the food waste, sawdust and the initial mix are given in Table 1.

\section{Enrichment of bacterial consortium and inoculum preparation}

About 20 indigenous bacterial consortia isolated from food waste compost and kitchen sink waste samples were enriched using $50 \mathrm{~mL}$ of modified basal salt liquid medium
Table 1. Selected physicochemical properties of the food waste, sawdust and their mix used as initial feed stock in the present study

\begin{tabular}{lccc} 
Parameter & Food waste & Sawdust & Mix \\
$\mathrm{pH}$ & $5.13 \pm 0.12$ & $4.99 \pm 0.10$ & $7.42 \pm 0.06$ \\
$\rho($ bulk $) /(\mathrm{kg} / \mathrm{L})$ & $0.63 \pm 0.02$ & $0.2 \pm 0.1$ & $0.5 \pm 0.2$ \\
$w$ (moisture)/\% & $71.2 \pm 2.6$ & $11.8 \pm 1.5$ & $56.8 \pm 2.7$ \\
$w$ (total organic carbon)/\% & $46.3 \pm 0.3$ & $54.7 \pm 0.3$ & $47.2 \pm 0.5$ \\
$w$ (total Kjeldahl nitrogen)/\% & $2.7 \pm 0.2$ & $0.3 \pm 0.1$ & $1.8 \pm 0.2$ \\
C/N ratio & $16.9 \pm 0.3$ & $165.8 \pm 0.2$ & $25.6 \pm 0.1$ \\
\hline
\end{tabular}

Values represent mean and standard deviation $(N=3)$

(SOB Medium, BD Difco ${ }^{\mathrm{TM}}$ dehydrated culture media, Thermo Fisher Scientific, Waltham, MA, USA) in 250-mL Erlenmeyer flask (Büchi Glass Uster AG, Uster, Switzerland). The food waste compost was obtained from our previous experiment, while kitchen sink waste was collected from university canteen (Northwest Agricultural and Forestry University, Yangling, PR China). The composition of basal salt medium (SOB Medium, BD Difco ${ }^{\mathrm{TM}}$ dehydrated culture media, Thermo Fisher Scientific) in $1 \mathrm{~L}$ of water was (in $\mathrm{g}$ ): $\mathrm{NaNO}_{3} 2$, $\mathrm{KH}_{2} \mathrm{PO}_{4} 2, \mathrm{Na}_{2} \mathrm{HPO}_{4} \cdot 12 \mathrm{H}_{2} \mathrm{O} 2, \mathrm{MgSO}_{4} \cdot 7 \mathrm{H}_{2} \mathrm{O} 0.2, \mathrm{CaCl}_{2} \cdot 2 \mathrm{H}_{2} \mathrm{O} 0.1$, $\mathrm{FeSO}_{4} \cdot 7 \mathrm{H}_{2} \mathrm{O} 0.001, \mathrm{NaCl} 0.8, \mathrm{KCl} 0.8$ and $1 \mathrm{~mL}$ of trace metal solution (composition (in g/L): $\mathrm{FeCl}_{3} 0.08, \mathrm{ZnSO}_{4} \cdot 7 \mathrm{H}_{2} \mathrm{O} 0.75$, $\mathrm{CoCl}_{2} \cdot 6 \mathrm{H}_{2} \mathrm{O} 0.08, \mathrm{CuSO}_{4} \cdot 5 \mathrm{H}_{2} \mathrm{O} 0.075, \mathrm{MnSO}_{4} \cdot 7 \mathrm{H}_{2} \mathrm{O} 0.75, \mathrm{H}_{3} \mathrm{BO}_{3}$ 0.15 and $\mathrm{Na}_{2} \mathrm{MoO}_{4} \cdot 2 \mathrm{H}_{2} \mathrm{O} 0.05$ ) in $47 \mathrm{~mL}$ of distilled water with 2 $\mathrm{mL}$ of vegetable oil (sunflower seed oil, Jia'n City Senhai Spice Co. Ltd., Jiangxi, PR China) (17).

The liquid medium was sterilized at $121^{\circ} \mathrm{C}$ and $15 \mathrm{~Pa}$ for $20 \mathrm{~min}$ and medium $\mathrm{pH}$ was adjusted to $7.0 \pm 0.1$ using $0.5 \mathrm{M}$ phosphate buffer solution (SOB Medium, BD DifCo ${ }^{\mathrm{TM}}$ dehydrated culture media, Thermo Fisher Scientific). The mass of $5 \mathrm{~g}$ of soil or food waste compost sample was inoculated into $50 \mathrm{~mL}$ of the above basal salt medium and incubated at $55^{\circ} \mathrm{C}$ on a rotary shaker (Heidolph Instruments, Schwabach, Germany) at $200 \mathrm{rpm}$ for 3 days and then $1 \mathrm{~mL}$ of culture was transferred to a fresh medium. The enrichment was repeated up to five times and then the enriched consortium was used for further experiment. The potential bacterial consortium was selected on the basis of in-vitro substrate-specific degradation experiment (data not shown). The enriched bacterial consortium was grown in nutrient broth medium (SOB Medium, BD Dif$\mathrm{CO}^{\mathrm{TM}}$ dehydrated culture media, Thermo Fisher Scientific) at $55^{\circ} \mathrm{C}$ on a rotary shaker at $200 \mathrm{rpm}$ for $24 \mathrm{~h}$ and then $2 \mathrm{~L}$ of broth culture $\left(6.8 \cdot 10^{6} \mathrm{CFU} / \mathrm{mL}\right.$ or that of which absorbance was greater than 1) was used as inoculum for composting, while control treatment was also mixed with $2 \mathrm{~L}$ of broth alone to obtain similar nutrient level in both treatments. A UV-Vis spectrophotometer (UVmini-1240; Shimadzu, Tokyo, Japan) was used to measure the absorbance of bacterial population.

\section{Experimental design and analyses}

The specially designed stainless steel in-vessel composter with feeding capacity of $60 \mathrm{~L}$ was used for the experiment (Shantou Transion Trading Co., Ltd., Shantou, PR China). The 
composting reactor was filled with $25 \mathrm{~kg}$ of fresh food waste mixed with sawdust (4:1 ratio on dry mass basis). Two composters were used: one composter served as a control, while in the other $2 \mathrm{~L}$ of enriched bacterial consortium were inoculated in the composting mix on the first day. The composting period lasted 42 days and during this period, the feedstock was mixed thoroughly by hand. Three representative samples of about $200 \mathrm{~g}$ were collected from control and treatment composters on turning days $0,3,7,10,14,21,28$ and 42 of the composting period. Then the $\mathrm{pH}$ (PHSJ-3F meter; INESA Analytical Instrument Co., Ltd., Shanghai, PR China), electrical conductivity (DDS-307 conductivity meter; INESA Analytical Instrument Co., Ltd.), total organic matter, extractable ammonium $\left(\mathrm{NH}_{4}^{+}-\mathrm{N}\right)$, total Kjeldahl nitrogen (TKN), total organic carbon (TOC), total phosphorus, total potassium, $\mathrm{NH}_{3^{\prime}}$ and carbon dioxide evolution and seed germination index were determined according to the standard methods of compost maturity analysis $(18,19)$.

\section{Statistical analysis}

The uncertainty of the analyzed parameters was measured by one-way analysis of variance (ANOVA) and Duncan's multiple range tests using SPSS v. 21 software (20). Redundancy analyses of analyzed parameters during composting were conducted by Canoco v. 5 software (21).

\section{RESULTS AND DISCUSSION}

\section{Changes in temperature and $\mathrm{pH}$}

Temperature is a critical parameter that indicates overall microbial activity, stability and maturity of end products. Changes in composting temperature strongly reflect the metabolic activity of microorganisms during composting $(22,23)$. Fig. 1 a reveals the variation of temperature during food waste composting under the employed conditions. In the compost reactor inoculated with bacterial consortium the temperature significantly increased and reached $68^{\circ} \mathrm{C}$ within 2 days, indicating that the inoculated microorganisms could easily decompose the organic matter of the food waste. The thermophilic phase was prolonged for more than 15 days in the composter inoculated with bacterial consortium, and then the temperature gradually dropped to the ambient level. In contrast, the temperature of control composting reactor increased slowly and reached a maximum of $60^{\circ} \mathrm{C}$ on day 10 . The slow increase in temperature resulted in a prolonged period of thermophilic phase, which lasted for 40 days, and then the temperature sharply dropped.

The temperature profile of control reactor clearly indicates that composting was slow in the absence of suitable microbial consortium that degrades the oil content. The temperatures exceeding $55^{\circ} \mathrm{C}$ for at least 3 days is an indication of elimination of pathogenic microbes during the composting. This level is highly suitable for the small-scale in-vessel food waste composting. Besides, $\mathrm{CO}_{2}$ evolution rate of control of $(7.7 \pm 0.5) \mathrm{g} /$ (kg.day) and treatment of $(0.8 \pm 0.2) \mathrm{g} /(\mathrm{kg} \cdot$ day $)$ showed a highly significant variation, which clearly reflected the role of enriched microbial inoculum in the treatment.

Variations in $\mathrm{pH}$ during the initial stages of composting are remarkably altered by microbial activity, and for optimal composting neutral $\mathrm{pH}$ was reported in several earlier works (2224). During initial phase of composting, the initial pH of compost mix ( $\mathrm{pH}=7.42)$ in the treatment with bacterial consortium significantly decreased to around 5.5 on day 3 (Fig. 1 b) and thereafter gradually increased to $\mathrm{pH} 7.7$ after 42 days, while in the control the $\mathrm{pH}$ drop continued until day 14 and reached $\mathrm{pH} 4$.0, then gradually increased with compost maturation and reached $\mathrm{pH} 6.5$ on day 42 . The initial reduction of $\mathrm{pH}$ to acidic range could be due to the organic acids produced during the early stage of composting and incomplete oxidation of organic matter. The subsequent increase in $\mathrm{pH}$ was due to the decomposition of organic acids and proteinaceous substrate combined with production of gaseous ammonia (25-28). Overall, the correlation analysis confirmed that temperature and $\mathrm{pH}$ have significant effect on the composting efficiency.
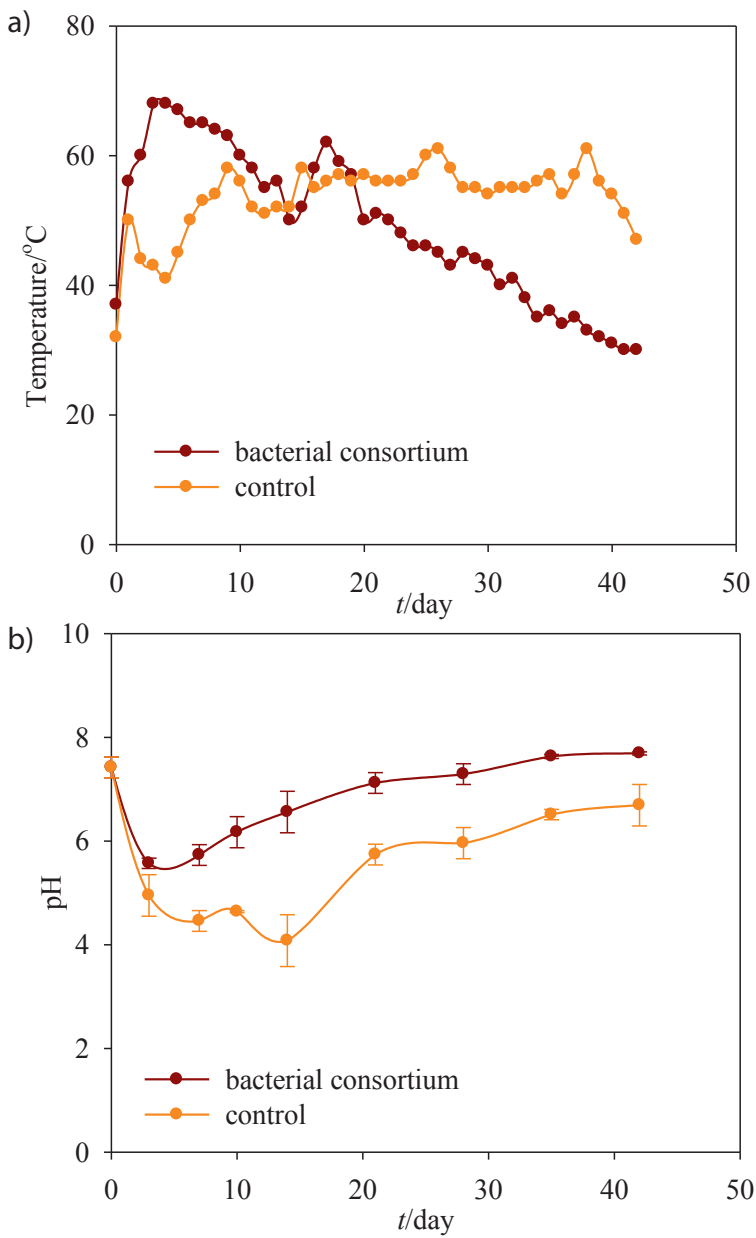

Fig. 1. Changes of: a) temperature profiles, and b) pH value of the composting mass during composting of food waste. Results are expressed as the mean value and standard deviation of triplicate samples 


\section{Total organic carbon and total Kjeldahl nitrogen}

The total organic carbon (TOC) contents in both the control and bacterial consortium treatment gradually decreased during composting. The TOC reduction was higher in the compost inoculated with the bacterial consortium (Fig. 2a), which is well corroborated with its temperature profile. Despite the later thermophilic period in the control, the TOC reduction was not as high as in the compost inoculated with bacterial consortium indicating that higher degradation of organic matter occurred in the treatment than in control. Since the bacterial population in the treatment was larger than in the control, more carbon was utilized by the microbes. Besides, inhibition of microbes due to acidic $\mathrm{pH}$ could also be a reason for the slow degradation of organic matter in the control.

The total Kjeldahl nitrogen (TKN) content rapidly decreased in the compost inoculated with bacterial consortium until day 7 of composting, while in the control the TKN continuously decreased until day 14 (Fig. 2b). This period of decreasing TKN correlates with the increase of $\mathrm{NH}_{4}^{+}-\mathrm{N}$, indicating that the reduction in TKN could be related to the loss of $\mathrm{NH}_{3^{\prime}}$, however, the $\mathrm{pH}$ during this period was not high enough to promote that. Therefore, further analysis and experiments are required to investigate this discrepancy in the oily food waste. After one and two weeks, the TKN increased gradually to approx. 2.06 and $1.45 \%$ in the treatment with bacterial consortium and control, respectively. Nitrogen loss during the first two weeks of composting and further increasing TKN trend during food waste composting were also reported in some earlier works (29-31).

\section{Extractable ammonium and $\mathrm{C} / \mathrm{N}$ ratio}

During the early stage of composting, degradation of organic matter releases ammonium and the prevailing $\mathrm{pH}$ influences the loss of this $\mathrm{NH}_{4}^{+}$as $\mathrm{NH}_{3}$ gas resulting in significant loss of nitrogen from the composting mass (32-36). $\mathrm{The}^{\mathrm{NH}_{4}{ }^{+} \text {mass }}$ fraction increased on day 14 of the treatment and on day 21 in control reactor; after that it gradually decreased until day 42 (Fig. 2c). The $\mathrm{NH}_{4}{ }^{+}$mass fraction quantified in the reactor with bacterial consortium was significantly $(p<0.05)$ lower than in the control composter (Fig. 2c). The final extractable $\mathrm{NH}_{4}^{+}$mass fraction of the treatment with bacterial consortium was below $500 \mathrm{mg} / \mathrm{kg}$, while in the control it was approx. $2000 \mathrm{mg} / \mathrm{kg}$, indicating that this compost may exert phytotoxic effect and needs a long period of maturity.

The $\mathrm{C} / \mathrm{N}$ ratio is an important parameter of the end product as it affects immobilization and release of nitrogen and other important macronutrients for plant growth (35-37). A decreasing trend of $\mathrm{C} / \mathrm{N}$ ratio throughout the composting period might be due to the higher loss of carbon compounds generally (Fig. 2d). Rapid decomposition of the organic matter coupled with increase in nitrogen content resulting from the loss of total organic matter led to the decrease in $\mathrm{C} / \mathrm{N}$ ratio as investigated earlier $(38,39)$. The $\mathrm{C} / \mathrm{N}$ ratio of the final product of bacterial consortium treatment was approx. 16, indicating good maturity of the compost and that it could be readily used as supplement a)

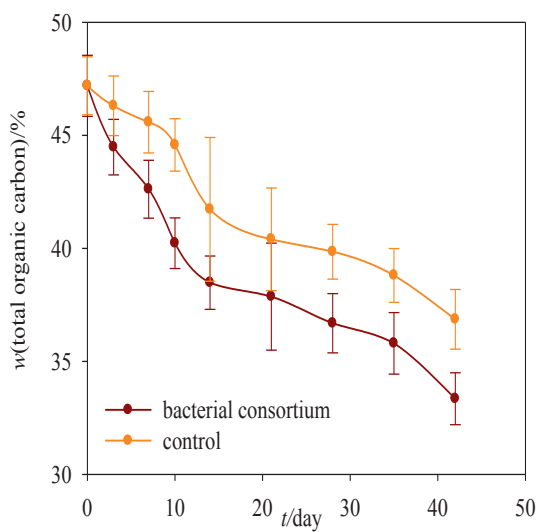

b)

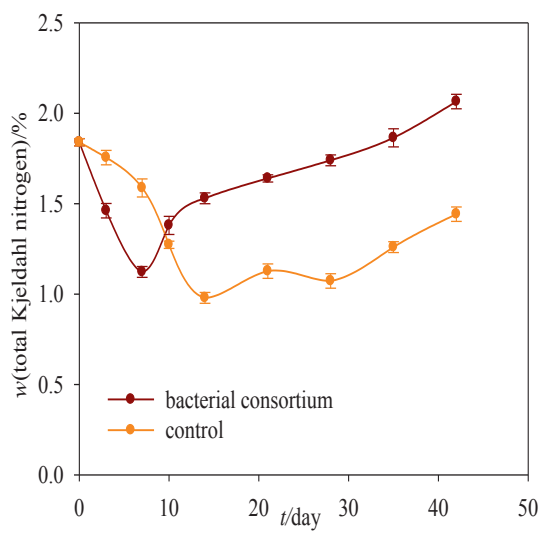

c)

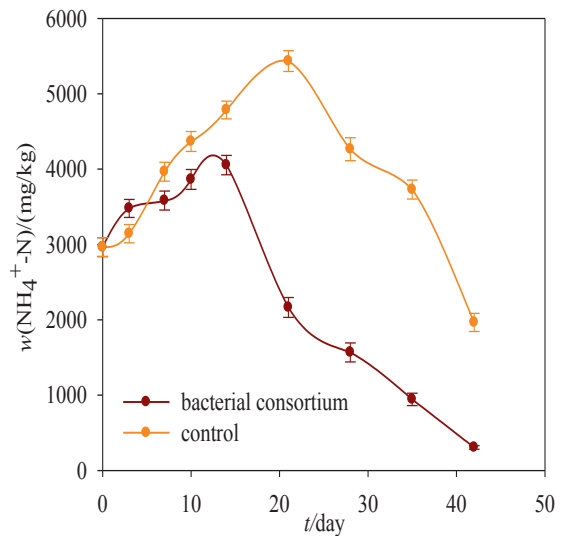

d)

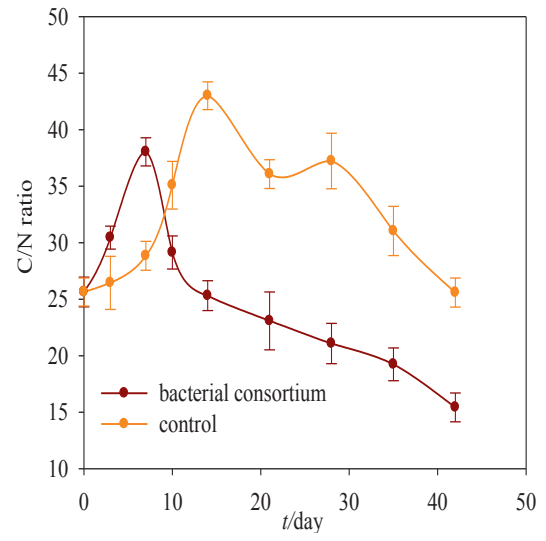

Fig. 2. Changes in: a) total organic carbon, b) total Kjeldahl nitrogen, c) extractable ammonium, and d) $\mathrm{C} / \mathrm{N}$ ratio during composting of food waste. Results are expressed as the mean value and standard deviation of triplicate samples 
for plant growth. In the control, the C/N ratio was approx. 25.41 , which is significantly $(p<0.05)$ higher than in the treatment with bacterial consortium. In addition, the correlation analysis also indicated that $\mathrm{C} / \mathrm{N}$ ratio was directly related to TOC and TKN mineralization profile (Fig. 3).

a)

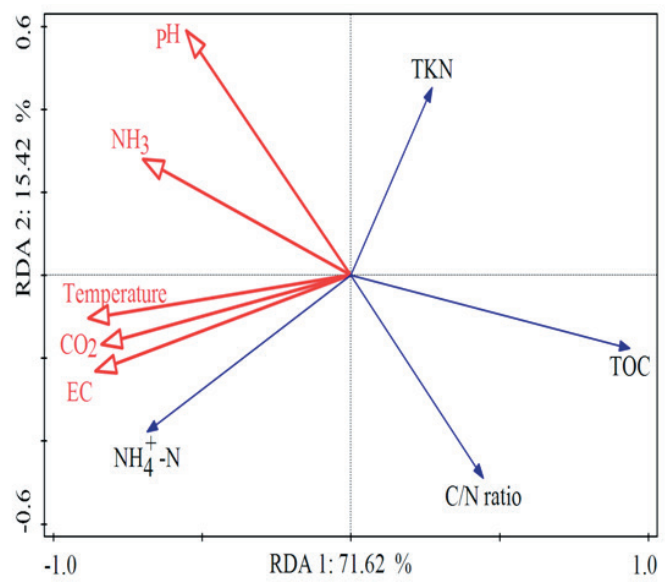

b)

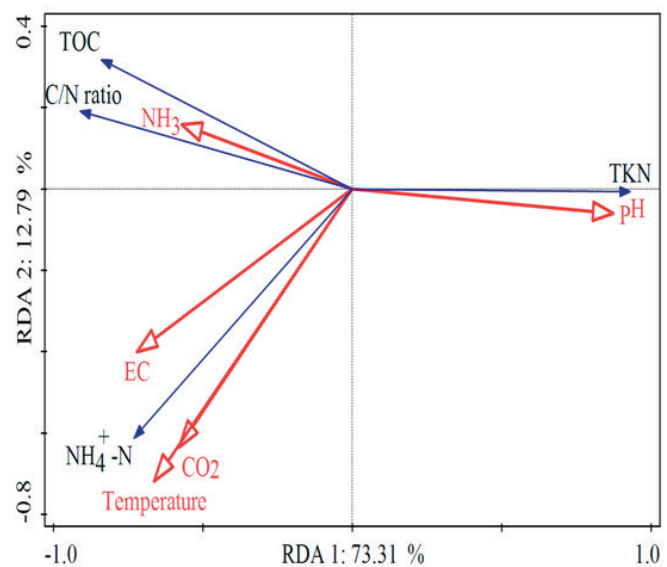

Fig. 3. Redundancy analysis: a) control, and b) bacterial consortium. TOC=total organic carbon, $\mathrm{TKN}=$ total Kjeldahl nitrogen, $\mathrm{EC}=$ electrical conductivity

\section{Cress seed germination index}

Seed germination index is important criterion for compost maturity evaluation, since it directly indicates if the final compost has an inhibitory effect on plant growth or not. Initially, the germination indices were very low (Fig. 4 and Table 2) due to the active decomposition of organic materials that generated a variety of toxic compounds and thus reduced the seed germination $(38,39)$. The germination index dropped on day 7 in the treatment with bacterial consortium and on day 10 in control, and then it gradually increased until the end of composting. On day 35, the germination index in the treatment with bacterial consortium reached $>90 \%$, while in the control treatment it did not reach $80 \%$, as required for the compost maturity after 42 days, indicating that the delayed thermophilic period and high mass fraction of $\mathrm{NH}_{4}^{+}$were clearly attributed to the poor germination index in the control and it required a longer period to reach maturity.

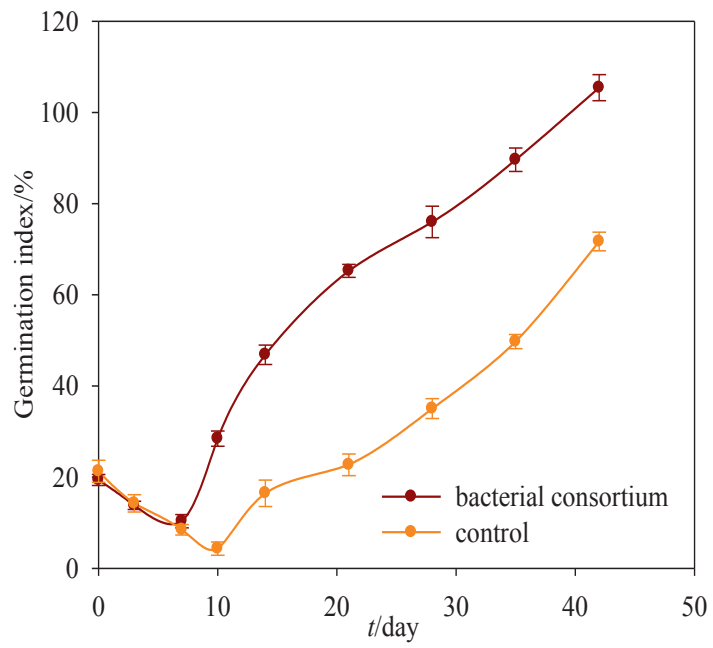

Fig. 4. Changes in germination index during composting of food waste. Results are expressed as the mean value and standard deviation of triplicate samples

Table 2. Maturity properties of compost obtained after composting of real food waste

\begin{tabular}{|c|c|c|c|c|}
\hline \multirow{2}{*}{ Parameter } & \multirow{2}{*}{ Control $^{\mathrm{a}}$} & \multirow{2}{*}{ Bacterial consortium ${ }^{a}$} & \multicolumn{2}{|c|}{ Compost standard } \\
\hline & & & $\mathrm{HKORC}^{\mathrm{b}}$ & TMECCC $/ C C M E ~^{d}$ \\
\hline$w\left(\mathrm{NH}_{4}^{+}-\mathrm{N}\right) /(\mathrm{mg} / \mathrm{kg})$ & $1965.4 \pm 32.1$ & $305.8 \pm 16.6$ & $\leq 700$ & $75-500$ \\
\hline $\mathrm{CO}_{2}$ evolution rate $/(\mathrm{g} /(\mathrm{kg} \cdot$ day $))$ & $7.7 \pm 0.5$ & $0.8 \pm 0.2$ & $\leq 2$ & $2-4$ \\
\hline $\mathrm{pH}$ & $6.65 \pm 0.04$ & $7.69 \pm 0.02$ & $5.5-8.5$ & - \\
\hline$\kappa /(\mathrm{mS} / \mathrm{cm})$ & $7.7 \pm 0.1$ & $3.7 \pm 0.2$ & $\geq 4$ & $\geq 4$ \\
\hline$w($ total organic carbon) $/ \%$ & $36.8 \pm 1.3$ & $33.3 \pm 1.2$ & $\geq 16$ & - \\
\hline$w($ total organic matter)/\% & $93.3 \pm 0.5$ & $85.6 \pm 0.4$ & $\geq 20$ & $\geq 40$ \\
\hline$w($ total Kjeldahl nitrogen)/\% & $1.45 \pm 0.05$ & $2.06 \pm 0.03$ & $1.0-3.0$ & - \\
\hline$w$ (total phosphorus)/\% & $1.4 \pm 0.5$ & $1.6 \pm 0.3$ & - & - \\
\hline$w($ total potassium) $/ \%$ & $1.8 \pm 0.3$ & $1.1 \pm 0.2$ & $0.6-1.7$ & $\geq 4$ \\
\hline$w(\mathrm{~N}+\mathrm{P}+\mathrm{K}) / \%$ & $4.7 \pm 0.5$ & $4.8 \pm 0.3$ & $\geq 4$ & - \\
\hline Germination index/\% & $71.7 \pm 13$ & $105.4 \pm 9.0$ & $\geq 80$ & $80-90$ \\
\hline $\mathrm{C} / \mathrm{N}$ ratio & $25.4 \pm 1.7$ & $16.2 \pm 1.4$ & $\leq 25$ & $\leq 25$ \\
\hline
\end{tabular}

${ }^{a}$ Mean value \pm standard deviation $(N=3)$, ' $H K O R C$, Compost and Soil Conditioner Quality Standards (36), 'TMECC, standards for 'stable' compost quality (18), ${ }^{d} \mathrm{CCME}$, guidelines for compost quality (37) 


\section{Compost quality}

The physicochemical properties of the finished compost from both treatments, i.e. the compost inoculated with bacterial consortium and control after 42 days are shown in Table 2. However, among the different analyzed maturity properties, the $\mathrm{CO}_{2}$ evolution rate of the compost inoculated with bacterial consortium was within the limits of $\leq 2.0 \mathrm{~g} /(\mathrm{kg} \cdot$ day $)$. The $\mathrm{pH}$ and electrical conductivity values also show that the compost inoculated with bacterial consortium is suitable for organic farming as the $\mathrm{C} / \mathrm{N}$ ratio was smaller than 20 . The germination index of the compost inoculated with bacterial consortium after 42 days of composting was more than $80 \%$, while it was $<80 \%$ in the control. A precise maturation period was observed of the compost inoculated with bacterial consortium. Accordingly, the results (Table 2) show that the availability of essential nutrients in the matured compost inoculated with bacteria was within the Compost and Soil Conditioner Quality Standards for Organic Farming (36) and Guidelines for Compost Quality (37).

\section{CONCLUSIONS}

The effect of enriched bacterial consortium and addition of $2 \%$ lime to increase the low $\mathrm{pH}$ and reduce oil content of real food waste composting was investigated in a small-scale in-vessel composter. The results clearly indicate that compost inoculated with bacterial consortium has rapid mineralization rates in the first 14 days of composting, and higher temperature. The compost inoculated with bacterial consortium matured within 5 to 6 weeks and met the standard for compost quality, while the control did not meet the required standard.

\section{ACKNOWLEDGEMENTS}

The authors are grateful for the financial support from China Yangling Demonstration Zone Collaborative Innovation Major Projects of Production, Study, Research and Application (No. 2016CXY-12) and China Postdoctoral Science Foundation (No. 2016M602865). We also thank all our laboratory colleagues and research staff members for their constructive advice and help.

\section{REFERENCES}

1. Zhou H, Meng AH, Long YQ, Li QH, Zhang YG. An overview of characteristics of municipal solid waste fuel in China: Physical, chemical composition and heating value. Renew Sustain Energy Rev. 2014;36:107-22. https://doi.org/10.1016/j.rser.2014.04.024

2. Sheng L, editor. China statistical yearbook. Beijing, PR China: China Statistics Press; 2016.

3. Wang X, Selvam A, Chan M, Wong JWC. Nitrogen conservation and acidity control during food wastes composting through struvite formation. Bioresour Technol. 2013;147:17-22.

https://doi.org/10.1016/j.biortech.2013.07.060
4. Abdullah N, Chin NL. Simplex-centroid mixture formulation for optimized composting of kitchen waste. Bioresour Technol. 2010;101:8205-10.

https://doi.org/10.1016/j.biortech.2010.05.068

5. Mondini C, Dell'Abate MT, Leita L, Benedetti A. An integrated chemical, thermal, and microbiological approach to compost stability evaluation. J Environ Qual. 2003;32:2379-86. https://doi.org/10.2134/jeq2003.2379

6. Sundberg C, Smårs S, Jönsson H. Low pH as an inhibiting factor in the transition from mesophilic to thermophilic phase in composting. Bioresour Technol. 2004;95:145-50. https://doi.org/10.1016/j.biortech.2004.01.016

7. Cheung HNB, Huang GH, Yu H. Microbial-growth inhibition during composting of food waste: Effects of organic acids. Bioresour Technol. 2010;101:5925-34. https://doi.org/10.1016/j.biortech.2010.02.062

8. Fang $\mathrm{M}$, Wong $\mathrm{MH}$, Wong JWC. Digestion activity of thermophilic bacteria isolated from ash-amended sewage sludge compost. Water Air Soil Pollut. 2001;126:1-12. https://doi.org/10.1023/A:1005270428647

9. Gabhane J, William SPMP, Bidyadhar R, Bhilawe P, Anand D, Vaidya AN, Wate SR. Additives aided composting of green waste: Effects on organic matter degradation, compost maturity, and quality of the finished compost. Bioresour Technol. 2012;114:382-8.

https://doi.org/10.1016/j.biortech.2012.02.040

10. Hosseini SM, Aziz HA. Evaluation of thermochemical pretreatment and continuous thermophilic condition in rice straw composting process enhancement. Bioresour Technol. 2013;133:240-7. https://doi.org/10.1016/j.biortech.2013.01.098

11. Huang DL, Zeng GM, Feng CL, Hu S, Lai C, Zhao MH, et al. Changes of microbial population structure related to lignin degradation during lignocellulosic waste composting. Bioresour Technol. 2010;101:4062-7. https://doi.org/10.1016/j.biortech.2009.12.145

12. Kim JD, Park JS, In BH, Kim D, Namkoong W. Evaluation of pilot-scale in-vessel composting for food waste treatment. J Hazard Mater. 2008;154:272-7. https://doi.org/10.1016/j.jhazmat.2007.10.023

13. Joo HS, Ndegwa PM, Shoda M, Phae CG. Bioremediation of oil-contaminated soil using Candida catenulata and food waste. Environ Pollut. 2008;156:891-6. https://doi.org/10.1016/j.envpol.2008.05.026

14. Wong JWC, Li SWY, Wong MH. Coal fly ash as a composting material for sewage sludge: Effects on microbial activities. Environ Technol. 1995;16:527-37. https://doi.org/10.1080/09593331608616294

15. Ke GR, Lai CM, Liu YY, Yang SS. Inoculation of food waste with the thermo-tolerant lipolytic actinomycete Thermoactinomyces vulgaris A31 and maturity evaluation of the compost. Bioresour Technol. 2010;101:7424-31. https://doi.org/10.1016/j.biortech.2010.04.051 
16. Tsai SH, Liu CP, Yang SS. Microbial conversion of food wastes for biofertilizer production with thermophilic lipolytic microbes. Renew Energy. 2007;32:904-15.

https://doi.org/10.1016/j.renene.2006.04.019

17. Atlas RM. Handbook of media for environmental microbiology. Boca Raton, FL, USA: CRC Press, Taylor \& Francis Group; 1995. pp. 310-5.

18. Thompson $\mathrm{W}$, Leege $\mathrm{P}$, Millner $\mathrm{P}$, Watson ME, editors. Test methods for the examination of compost and composting (TMECC). Reston, VA, USA: Composting Council; 2002.

19. Zucconi F, Monaco A, Forte M, Beritodi M. Phytotoxins during the stabilization of organic matter. In: Gasser JKR, editor. Composting of agricultural and other wastes. London, UK; Elsevier Applied Sciences; 1985. pp. 73-86.

20. IBM SPSS Statistics. v. 21.0, IBM Corporation, Armonk, NY, USA; 2016. Available from: https://www-01.ibm.com/support/docview.wss?uid=swg21608060.

21. ter Braak, CJF, Smilauer P. Canoco reference manual and CanoDraw for Windows user's guide: Software for canonical community ordination, v. 5. Ithaca, NY, USA: Microcomputer Power; 2002.

22. Sarkar S, Banerjee R, Chanda S, Das P, Ganguly S, Pal S. Effectiveness of inoculation with isolated Geobacillus strains in the thermophilic stage of vegetable waste composting. Bioresour Technol. 2010;101:2892-5.

https://doi.org/10.1016/j.biortech.2009.11.095

23. Kopčić N, Vuković Domanovac M, Kučić D, Briški F. Evaluation of laboratory-scale in-vessel co-composting of tobacco and apple waste. Waste Manag. 2014;34:323-8. https://doi.org/10.1016/j.wasman.2013.11.001

24. Kuok F, Mimoto H, Nakasaki K. Effects of turning on the microbial consortia and the in situ temperature preferences of microorganisms in a laboratory-scale swine manure composting. Bioresour Technol. 2012;116:421-7.

https://doi.org/10.1016/j.biortech.2012.03.106

25. Choi MH, Park YH. The influence of yeast on thermophilic composting of food waste. Lett Appl Microbiol. 1998;26:175-8.

https://doi.org/10.1046/j.1472-765X.1998.00307.x

26. López-González JA, López MJ, Vargas-García MC, Suárez-Estrella F, Macarena J, Moreno J. Tracking organic matter and microbiota dynamics during the stages of lignocellulosic waste composting. Bioresour Technol. 2013;146:574-84.

https://doi.org/10.1016/j.biortech.2013.07.122

27. Huang GF, Wong JWC, Wu QT, Nagar BB. Effect of C/N on composting of pig manure with sawdust. Waste Manag. 2004;24:805-13.

https://doi.org/10.1016/j.wasman.2004.03.011

28. Nakasaki K, Yaguchi H, Sasaki Y, Kubota H. Effects of pH control on composting of garbage. Waste Manag Res.
1993;11:117-25.

https://doi.org/10.1177/0734242X9301100204

29. Said-Pullicino D, Erriquens FG, Gigliotti G. Changes in the chemical characteristics of water-extractable organic matter during composting and their influence on compost stability and maturity. Bioresour Technol. 2007;98:1822-31. https://doi.org/10.1016/j.biortech.2006.06.018

30. Sellami F, Jarboui R, Hachicha S, Medhioub K, Ammar E. Co-composting of oil exhausted olive-cake, poultry manure and industrial residues of agro-food activity for soil amendment. Bioresour Technol. 2008;99:1177-88. https://doi.org/10.1016/j.biortech.2007.02.018

31. Seng B, Hirayama K, Katayama-Hirayama K, Ochiai S, Kaneko H. Scenario analysis of the benefit of municipal organic-waste composting over landfill, Cambodia. J Environ Manage. 2013;114:216-24.

https://doi.org/10.1016/j.jenvman.2012.10.002

32. Wong JWC, Fung SO, Selvam A. Coal fly ash and lime addition enhances the rate and efficiency of decomposition of food waste during composting. Bioresour Technol. 2009;100:3324-31.

https://doi.org/10.1016/j.biortech.2009.01.063

33. Wong WJC, Fang M. Effects of lime addition on sewage sludge composting process. Water Res. 2000;34:3691-8. https://doi.org/10.1016/S0043-1354(00)00116-0

34. Wang X, Selvam A, Chan M, Wong JWC. Nitrogen conservation and acidity control during food wastes composting through struvite formation. Bioresour Technol. 2013;147:17-22.

https://doi.org/10.1016/j.biortech.2013.07.060

35. Wang X, Selvam A, Wong JWC. Influence of lime on struvite formation and nitrogen conservation during food waste composting. Bioresour Technol. 2016;217:227-32. https://doi.org/10.1016/j.biortech.2016.02.117

36. Compost and Soil Conditioner Quality Standards. Hong Kong Organic Resource Centre (HKORC). Hong Kong, PR China: Hong Kong Baptist University; 2005. Available from: https://www.hkorc-cert.org/download/COMPOST-SD-080124- A-Eng.pdf.

37. Guidelines for Compost Quality. Canadian Council of the Ministers of the Environment (CCME). Winnipeg, Manitoba, Canada: Canadian Council of Ministers of the Environment; 2005.

38. Awasthi MK, Selvam A, Chan MT, Wong JWC. Bio-degradation of oily food waste employing thermophilic bacterial strains. Bioresour Technol. 2018;248:141-7. https://doi.org/10.1016/j.biortech.2017.06.115

39. Wang X, Selvam A, Lau SSS, Wong JWC. Influence of lime and struvite on microbial community succession and odour emission during food waste composting. Bioresour Technol. 2018;247:652-9. https://doi.org/10.1016/j.biortech.2017.07.091 